\title{
Organic Matter and Barium Absorption by Plant Species Grown in an Area Polluted with Scrap Metal Residue
}

\author{
Cleide Aparecida Abreu, ${ }^{1}$ Mariana Cantoni, ${ }^{2}$ Aline Renée Coscione, ${ }^{1}$ \\ and Jorge Paz-Ferreiro ${ }^{3}$ \\ ${ }^{1}$ Centro de Solo e Recursos Ambientais, IAC, Avenida Barão de Itapura, 1481, 13020-902 Campinas, SP, Brazil \\ ${ }^{2}$ Programa de Pós-Graduação em Agricultura Tropical e Subtropical, IAC, 13020-902 Campinas, SP, Brazil \\ ${ }^{3}$ Departamento de Edafología, Universidad Politécnica de Madrid, 28004 Madrid, Spain
}

Correspondence should be addressed to Jorge Paz-Ferreiro, jpaz@udc.es

Received 18 October 2011; Revised 27 December 2011; Accepted 8 January 2012

Academic Editor: Philip White

Copyright ( 2012 Cleide Aparecida Abreu et al. This is an open access article distributed under the Creative Commons Attribution License, which permits unrestricted use, distribution, and reproduction in any medium, provided the original work is properly cited.

The effect of organic matter addition on Ba availability to Helianthus annuus L., Raphanus sativus L., and Ricinus communis L. grown on a Neossolo Litólico Chernossólico fragmentário ( $\mathrm{pH} 7.5)$, contaminated with scrap residue was evaluated. Four rates $\left(0,20,40\right.$, and $80 \mathrm{Mg} \mathrm{ha}^{-1}$, organic carbon basis) of peat or sugar cane filter, with three replicates, were tested. Plant species were grown until the flowering stage. No effect of organic matter addition to soil on dry matter yield of oilseed radish shoots was observed, but there was an increase in sunflower and castor oil plant shoots when sugar cane filter cake was used. The average Ba transferred from roots to shoots was more than $89 \%$ for oilseed radish, $71 \%$ for castor oil plants, and 59\% for sunflowers. Organic matter treatments were not efficient in reducing Ba availability due to soil liming.

\section{Introduction}

Accumulation of some chemical elements in the environment is of great concern because they can reach concentrations that may cause risks to human health and to the environment. Their concentration in soils depends on lithogenic and pedogenic processes, but also on anthropogenic activities. Soil pollution is a serious problem in many countries around the world. In São Paulo State, Brazil, since 2002, when the first survey was performed by the local environmental agency, more than 1600 contaminated areas have been identified [1].

The extensive industrial use of barium (Ba) adds up to the release of $\mathrm{Ba}$ in the environment and, as a result, $\mathrm{Ba}$ concentrations in air, water, and soil may be higher than naturally occurring concentrations on many locations [25]. Recently, it was observed that successive sewage sludge applications increased soil Ba concentration and accumulation in maize plants grown in the State of São Paulo [6]. Some research has shown probable Ba toxicity in plants, but such studies were short term and performed in nutrient solution
$[7,8] . \mathrm{Ba}$ is an alkaline earth element which occurs as a trace metal in igneous and sedimentary rocks. In nature it occurs mainly as low soluble minerals such as barite $\left(\mathrm{BaSO}_{4}\right)$ and witherite $\left(\mathrm{BaCO}_{3}\right)$. Ba solubilization and, consequently, the release of $\mathrm{Ba}^{2+}$ ions may occur under specific conditions. It has been shown to happen in acidic conditions [9], in the absence of oxygen, or even due to microbial action [10-13]. In contrast, $\mathrm{Ba}$ precipitates as a sulfate and/or carbonate salt in neutral or basic $\mathrm{pH}$ conditions. Therefore, the mobility of $\mathrm{Ba}$ is negligible in neutral or basic $\mathrm{pH}$ conditions, thus, reducing the risks of leaching and harmful health effects.

The application of lime and the addition of organic materials are considered the most efficient options to reduce heavy metal availability in soils [14-16]. The use of organic matter in chemically degraded areas can also be beneficial since plant development in such areas is frequently affected, exposing the soil to physical degradation.

Peat and humic materials concentrate reduced extractable $\mathrm{Zn}, \mathrm{Cu}, \mathrm{Pb}$, and $\mathrm{B}$ in soil and mustard shoots [14] while liming reduced the available concentrations of $\mathrm{Cd}, \mathrm{Pb}, \mathrm{Cu}$, and $\mathrm{Zn}$ in soils as well as its content in velvetbean shoots 
TABLE 1: Chemical composition of the organic materials*.

\begin{tabular}{lcccccccccccc}
\hline Source & $\mathrm{pH}$ & $\begin{array}{c}\text { E.C. } \\
\mathrm{dS} \mathrm{m}{ }^{-1}\end{array}$ & $\begin{array}{c}\text { O.C. } \\
\mathrm{g} \mathrm{kg}^{-1}\end{array}$ & $\mathrm{C} / \mathrm{N}$ & $\mathrm{P}$ & $\mathrm{K}$ & $\mathrm{Ca}$ & $\begin{array}{c}\mathrm{Mg} \\
\mathrm{g} \mathrm{kg}^{-1}\end{array}$ & $\mathrm{~B}$ & $\mathrm{Cu}$ & $\begin{array}{c}\mathrm{Fe} \\
\mathrm{Mg} \mathrm{kg}^{-1}\end{array}$ \\
\hline $\begin{array}{l}\text { Sugar } \\
\begin{array}{l}\text { cane } \\
\text { filter cake }\end{array}\end{array}$ & 7.5 & 0.9 & 263.7 & 12 & 10.3 & 2.3 & 16.2 & 3.7 & 21 & 60 & 5900 & 557 \\
\begin{tabular}{l} 
Peat \\
\hline
\end{tabular} & 5.5 & 0.2 & 163.1 & 24 & 0.8 & 1.4 & 1.7 & 1.7 & 16 & 45 & 6300 & 47 \\
\hline
\end{tabular}

E.C.: electrical conductivity; O.C.: organic carbon.

* Total elements concentration obtained by extraction with a mix of nitric and perchloric acids [17], results presented are the average of six replicates.

[16].The bioavailability of heavy metals to soybean and black-oat cultures was close to zero, when $8 \mathrm{Mg} \mathrm{ha}^{-1}$ sewage sludge, flue dust, and aqueous lime was applied to soil surface in no-till system [15]. However, lime and organic matter addition to the $\mathrm{Ba}$ contaminated soil and its availability to soil and its plants absorption have not received a great deal of attention and few information on the topic has been reported. The organic matter complexation of $\mathrm{Ba}$ ions can lead to insoluble species, decreasing the availability of Ba and enabling the growth of vegetation in highly contaminated areas [3]. Consequently, Ba effects on plant grown in soils containing Ba still needs to be further investigated.

The aim of the present work was to evaluate the effect of application rates of peat and sugar cane filter cake on $\mathrm{Ba}$ concentration in soil and its potential availability to sunflowers (Helianthus annuus L.), oilseed radish (Raphanus sativus L.), and castor oil plants (Ricinus communis L.) grown in a soil $(\mathrm{pH} 7.5)$ contaminated with scrap metal residue.

\section{Material and Methods}

In 2005, automobile scrap "shredder residue" was applied to the soil of an agricultural area of approximately 3 ha located in Piracicaba $\left(22^{\circ} 42^{\prime} 30^{\prime \prime} \mathrm{S}, 47^{\circ} 38^{\prime} 01^{\prime \prime} \mathrm{W}\right)$, São Paulo State, Brazil. The residue's metal content, obtained by the SW-846 3051 method [18] was, in $\mathrm{mg} \mathrm{kg}^{-1}$ : 170 of B, 7.4 of Cd, 2497 of $\mathrm{Cu}, 775$ of $\mathrm{Pb}, 178$ of $\mathrm{Cr}, 153$ of $\mathrm{Ni}, 8157$ of $\mathrm{Zn}$, and 920 of $\mathrm{Ba}$. Residue addition was performed based on the supposition that it may provide $\mathrm{Zn}$ and $\mathrm{Cu}$ to sugar cane crops, and the residue was incorporated into the soil at a depth of $30 \mathrm{~cm}$. The local environmental agency (CETESB) later verified that the area was contaminated by heavy metals (copper and zinc) and boron. Lime $\left(10 \mathrm{Mg} \mathrm{ha}^{-1}\right)$ was added to the soil in order to reduce heavy metals mobility and potential leaching. The soil in this area is classified as Lithic Udorthent [19].

Soil samples were taken from the $0-20 \mathrm{~cm}$ depth layer, dried at room temperature, and sieved to $2.0 \mathrm{~mm}$. The soil fertility attributes were measured as follows: $\mathrm{pH}_{\mathrm{CaCl} 2}=$ 7.5; $\mathrm{MO}=30.5 \mathrm{~g} \mathrm{dm}^{-3} ; \mathrm{P}_{\text {resin }}=43.3 \mathrm{mg} \mathrm{dm}^{-3} ; \mathrm{K}_{\text {resin }}=$ $2.6 \mathrm{mmol}_{\mathrm{c}} \mathrm{dm}^{-3} ; \mathrm{Ca}_{\text {resin }}=294 \mathrm{mmol}_{\mathrm{c}} \mathrm{dm}^{-3} ; \mathrm{Mg}_{\text {resin }}=$ $59 \mathrm{mmol}_{\mathrm{c}} \mathrm{dm}^{-3} ; \quad \mathrm{CEC}=364 \mathrm{mmol}_{\mathrm{c}} \mathrm{dm}^{-3} ; \mathrm{H}+\mathrm{Al}=$ $9.0 \mathrm{mmol}_{\mathrm{c}} \mathrm{dm}^{-3} ; \mathrm{V}=98 \%$ according to [20]. For the determination $\mathrm{P}, \mathrm{K}, \mathrm{Ca}$ a mixed (cationic and anionic) ion exchange resin method (Amberlite IRA 120 and Amberlite IRA 400) was used to simulate elements soil availability. It employs a ratio of 2.5 of soil per $2.5 \mathrm{~cm}^{3}$ of resin, which is kept in contact for 16 hours. The elements adsorbed by resin are washed away with $50 \mathrm{~mL}$ of a $0.8 \mathrm{~mol} \mathrm{~L}^{-1} \mathrm{NH}_{4} \mathrm{Cl}$ $+0.2 \mathrm{~mol} \mathrm{~L}^{-1} \mathrm{HCl}$, producing an extract where the elements are determined. Some of total elements content in the soil were measured by SW-846 3051 method [20] as follows, in mg kg-1: 241 of Ba, 62 of B, 4.3 of Cd, 335 of $\mathrm{Cu}, 332$ of $\mathrm{Pb}, 88.2$ of $\mathrm{Cr}, 53.6$ of $\mathrm{Ni}$, and 2998 of $\mathrm{Zn}$. This procedure consists of adding $10 \mathrm{~mL}$ of $\mathrm{HNO}_{3}$ to $500 \mathrm{mg}$ soil in a teflon capped vessel in a laboratory microwave system (CEM, Mars 5 model, Xpress vessels). The extraction is performed by raising the temperature to $170^{\circ} \mathrm{C}$ for $5 \mathrm{~min}$ and keeping it at this temperature during 10 minutes.

The experiment was carried out in a greenhouse at Campinas (São Paulo State, Brazil) in plastic pots $\left(5 \mathrm{dm}^{-3}\right)$. The following plant species: sunflowers (Helianthus annuus L.), oilseed radish (Raphanus sativus L.), and castor oil plants (Ricinus communis L.) were selected for the experiment due to previous works showing them to be tolerant to high concentration of heavy metals and boron in soil [21-24].

The experimental design was in randomized complete blocks with four rates $\left(0,20,40\right.$, and $80 \mathrm{Mgha}^{-1}$, organic carbon basis) of two organic matter sources (peat and sugar cane filter cake), with three replicates. The treatments were applied at $\left(\mathrm{g} \mathrm{pot}^{-1}\right): 0.0,37.9,75.8$, and $151.6 \mathrm{~g}$ of sugar cane filter cake per pot, respectively and $0.0,61.3,122.6$, and $245.2 \mathrm{~g}$ of peat per pot. The chemical compositions of the peat and sugar cane filter cake (Table 1) were obtained by determination of elements in a $0.5 \mathrm{mg}$ of sample extractred with nitric perchloric acids (3:1 ratio) [17].

The soil/organic materials were carefully homogenized and incubated at room temperature for 20 days with soil moisture maintained at $60 \%$ water holding capacity (WHC). The pots received $200 \mathrm{mg} \mathrm{kg}^{-1}$ of $\mathrm{P}$ as triple superphosphate $\left(41 \% \mathrm{P}_{2} \mathrm{O}_{5}\right)$ and the samples were homogenized and incubated for an additional 15 days after the sowing of seeds.

Three sunflowers and castor oil plants and ten oilseed radish were grown per pot. Deionized water was supplied by weighing the pots daily and adding the water needed to maintain $60 \%$ WHC. Nitrogen $\left(30 \mathrm{mg} \mathrm{N} \mathrm{kg}^{-1}\right.$ soil) was applied as ammonium nitrate $(32 \% \mathrm{~N})$ on emerging seedlings and again 15 days later.

Sunflower and oilseed radish were harvested 65 days after sowing, while castor oil plants were harvested 74 days after sieving. Shoots were separated from roots at harvest. The flowers were also separated when the oilseed radish and sunflowers were harvested. Roots were sieved, washed 
and soaked for $90 \mathrm{~min}$ in a solution of $0.02 \mathrm{mmol} \mathrm{L}^{-1}$ EDTA (disodium salt). After soaking, the oilseed radish roots were washed again with distilled water. Plant samples were washed, dried, and weighed and then digested using $\mathrm{HNO}_{3} / \mathrm{H}_{2} \mathrm{O}_{2}$ in a CEM Mars 5 microwave oven and analyzed for macro- and micronutrients, and barium, lead, cadmium, chromium, and nickel.

Soil samples collected after incubation were air-dried and sieved through a $2 \mathrm{~mm}$ mesh screen and then characterized for total and available metal contents. Available $\mathrm{Ba}$ content was analyzed using Mehlich-3 method $\left(\mathrm{CH}_{3} \mathrm{COOH}\right.$ $0.2 \mathrm{~mol} \mathrm{~L}^{-1}+\mathrm{NH}_{4} \mathrm{NO}_{3} 0.25 \mathrm{~mol} \mathrm{~L}^{-1}+\mathrm{NH}_{4} \mathrm{~F} 0.015 \mathrm{~mol} \mathrm{~L}^{-1}$ $+\mathrm{HNO}_{3} 0.015 \mathrm{~mol} \mathrm{~L}^{-1}+$ EDTA $0.001 \mathrm{~mol} \mathrm{~L}^{-1}$ at $\mathrm{pH} 2.5$ ) by agitation of five $\mathrm{cm}^{3}$ of soil and $20 \mathrm{~mL}$ the Mehlich-3 solution for $5 \mathrm{~min}$ [25]. The availability of several nutrients $(\mathrm{P}, \mathrm{K}, \mathrm{Ca}$, and $\mathrm{Mg}$ ) was evaluated by the ion exchange method [20].

$\mathrm{Ba}$ transported from soil to shoots was evaluated using the transfer factor $(\mathrm{TF})$ as follows: $\mathrm{TF}=\mathrm{PC}\left(\mathrm{mg} \mathrm{kg}^{-1}\right) / \mathrm{SC}$ $\left(\mathrm{mg} \mathrm{kg}^{-1}\right)$, where $\mathrm{CP}$ is the $\mathrm{Ba}$ concentration in the whole plant (root and shoot), and $\mathrm{CT}$ is the concentration of $\mathrm{Ba}$ in the soil [26]. The ability of each species to translocate $\mathrm{Ba}$ from the roots to the shoots was calculated using the following translocation index (TI): TI (\%) = QPA $\left(\mathrm{mg} \mathrm{pot}^{-1}\right) / \mathrm{QAP}$ $\left(\mathrm{mg} \mathrm{pot}^{-1}\right) \times 100$, where QPA is the element accumulation in the shoots, and QAP is the element accumulation in the whole plant (shoots and roots) [26].

The plant efficiency for the removal of elements (removal factor, $E$ ) was calculated using the following equation: $E(\%)=\mathrm{QPA}\left(\mathrm{mg} \mathrm{pot}^{-1}\right) / \mathrm{QR}\left(\mathrm{mg} \mathrm{pot}^{-1}\right) \times 100$, where $\mathrm{QR}$ is the amount of $\mathrm{Ba}$ to be removed from the soil $\left(\mathrm{mg} \mathrm{pot}^{-1}\right)$ [27]. When considering a $75 \%$ reduction of Ba concentration in the soil as a target, the time ( $T$, in years) needed for $\mathrm{Ba}$ removal was calculated as follows: $T=(R / E) / \mathrm{NC}$, where $R$ is the percentage of $\mathrm{Ba}$ reduction in the soil, $E$ is the removal factor, and NC is the number of crop cycles/year (considered as 1 cycle/year).

The data were submitted to analyses of variance (ANOVA), and the mean values were compared according to Tukey's test $(P \leq 0.05)$. When significant, the results obtained with the different concentrations of organic material were also examined using regression analysis (linear and quadratic models tested).

\section{Results and Discussion}

The concentration of $\mathrm{Ba}$ found during the soil characterization $\left(241 \mathrm{mg} \mathrm{kg}^{-1}\right)$ was close to the intervention levels (300 $\mathrm{mg} \mathrm{kg}^{-1}$ ) established by the Environmental Agency of the State of São Paulo [28]. Although the concentration of zinc, copper, and boron in this area is also worrisome, the use of plants that could help to remediate the soil was studied on previous works and was not significant in the present work as also discussed below [24, 29].

Mehlich-3 available Ba increased in soils amended with $40 \mathrm{Mgha}^{-1}$ of peat and $80 \mathrm{Mg} \mathrm{ha}^{-1}$ of sugar cane filter cake, with an average of $32.9 \mathrm{mg} \mathrm{dm}^{-3}$ in the soils amended with sugar cane filter cake and $36.2 \mathrm{mg} \mathrm{dm}^{-3}$ in the soils amended with peat (Table 2), which corresponded to a $12.3 \%$ and
TABLE 2: Ba extracted from soil with the Mehlich-3 method*.

\begin{tabular}{|c|c|c|}
\hline Rate & Sugar cane filter cake & Peat \\
\hline $\mathrm{Mg} \mathrm{ha}^{-1}$ & \multicolumn{2}{|c|}{$\mathrm{mg} \mathrm{dm} \mathrm{m}^{-3}$} \\
\hline 0 & $31.5 \mathrm{a}$ & $34.9 \mathrm{a}$ \\
\hline 20 & $32.9 \mathrm{a}$ & $34.1 \mathrm{a}$ \\
\hline 40 & $32.9 \mathrm{a}$ & $36.7 \mathrm{ab}$ \\
\hline 80 & $34.6 \mathrm{~b}$ & $39.3 \mathrm{~b}$ \\
\hline Average & $32.9 \mathrm{~A}$ & $36.2 \mathrm{~A}$ \\
\hline
\end{tabular}

* Results presented are the average of 3 replicates. Means followed by the same letter are not significantly different by the Tukey's test at $P \leq 0.05$. Upper case letters, in columns, compare treatments and lower case letters, in lines, compare rate of amendments.

$14.4 \%$ recovery, respectively. The recovery found in this study was lower than the one reported by others which was in a range from $50 \%$ to $78 \%$ [30]. The correlation between extractable $\mathrm{Ba}$ and soil organic carbon was $0.96 P<0.05$ (sugar cane filter cake) and $0.95 P<0.05$ (peat). However, no significant correlation was found between extractable $\mathrm{Ba}$ in the soil and the $\mathrm{Ba}$ accumulated in all of the plant tissues.

In most plants, the concentration of $\mathrm{Ba}$ ranges from 4 to $50 \mathrm{mg} \mathrm{kg}^{-1}$ [31], and concentrations of 200 and $500 \mathrm{mg} \mathrm{kg}^{-1}$ are considered to be slightly toxic or toxic, respectively [32]. The average $\mathrm{Ba}$ concentrations in the shoots after addition of sugar cane filter cake or peat were as follows: 44.47 or $50.97 \mathrm{mg} \mathrm{kg}^{-1}$, respectively, in sunflowers; 29.68 or $30.03 \mathrm{mg} \mathrm{kg}^{-1}$, respectively, in castor oil plants; and 77.23 or $74.46 \mathrm{mg} \mathrm{kg}^{-1}$, respectively, in oilseed radish (Table 3 ). Similar results have been reported for the same plant species grown in Rhodic Hapludox using $\mathrm{BaSO}_{4}$ additions of 0 , 150 , and $300 \mathrm{mg} \mathrm{kg}^{-1}$. The plant tissue Ba concentrations found in the present study were higher than previously reported $\left(21.3 \mathrm{mg} \mathrm{kg}^{-1}\right.$ for sunflowers, $19.4 \mathrm{mg} \mathrm{kg}^{-1}$ for mustard plants, and $10.6 \mathrm{mg} \mathrm{kg}^{-1}$ for castor oil plants [30]).

However, $\mathrm{Ba}$ concentrations in this study were less than those reported by Suwa et al., 2008 [8] who observed that high $\mathrm{Ba}$ concentrations affected soybeans and resulted in reduced development, stomatal closing, and reduced photosynthetic activity. In contrast, Ba accumulation in maize plants grown in soil with much lower Ba concentrations (soil $\mathrm{pH}$ in the range of 5.1 to 5.7) has also been reported and no phytotoxic symptoms or nutritional imbalance correlations were observed [6].

In this study no effects or symptoms of phytotoxicity were found in the plants. Moreover, no nutritional imbalance was observed in the soil samples. In the presence of high Ca concentrations, such as those of the area studied, Ba can precipitate [9]. The absence of phytotoxic in this study might bel explained by the high levels of available $\mathrm{Ca}\left(294 \mathrm{mmol}_{\mathrm{c}}\right.$ $\mathrm{dm}^{-3}$ ).

Shoot dry matter yields varied depending on the treatment and plant species (Table 4). Among the species tested, oilseed radish was the least affected by the treatments, and the peat addition promoted a higher dry matter yield in the oilseed radish roots. Sunflowers and castor oil plants showed similar results regarding shoot and root dry matter production, which were both higher when the sugar cane 
TABLE 3: Barium in plant parts of the tested species according to the rate of organic material treatment*.

\begin{tabular}{|c|c|c|c|c|c|c|c|c|c|c|c|}
\hline & \multirow{2}{*}{ Rate } & \multicolumn{4}{|c|}{ Oilseed radish } & \multicolumn{4}{|c|}{ Sunflower } & \multicolumn{2}{|c|}{ Castor oil plant } \\
\hline & & Root & Straw $(S)$ & Pod (P) & $S+P$ & Root & Straw $(S)$ & Flower (F) & $S+F$ & Roots & Shoots \\
\hline & $\mathrm{Mgha}^{-1}$ & \multicolumn{10}{|c|}{$\mathrm{mg} \mathrm{kg}^{-1}$} \\
\hline \multirow{4}{*}{$\begin{array}{l}\text { Sugar cane } \\
\text { filter cake }\end{array}$} & 0 & $111.0 \mathrm{a}$ & $56.6 \mathrm{a}$ & $19.2 \mathrm{a}$ & $75.8 \mathrm{a}$ & $76.7 \mathrm{a}$ & $31.1 \mathrm{a}$ & $18.5 \mathrm{a}$ & $49.56 \mathrm{a}$ & $39.8 \mathrm{~b}$ & 30.1 ba \\
\hline & 20 & 109.7 a & $56.0 \mathrm{a}$ & $21.3 \mathrm{a}$ & $77.3 \mathrm{a}$ & $76.0 \mathrm{a}$ & $32.2 \mathrm{a}$ & $15.2 \mathrm{~b}$ & $47.4 \mathrm{ba}$ & $53.1 \mathrm{a}$ & $31.7 \mathrm{a}$ \\
\hline & 40 & $105.0 \mathrm{a}$ & $58.5 \mathrm{a}$ & $20.7 \mathrm{a}$ & $79.2 \mathrm{a}$ & $75.0 \mathrm{a}$ & $27.8 \mathrm{ba}$ & $15.5 \mathrm{ba}$ & $43.4 \mathrm{bc}$ & $46.5 \mathrm{ba}$ & $30.9 \mathrm{a}$ \\
\hline & 80 & $103.8 \mathrm{a}$ & $56.8 \mathrm{a}$ & $19.7 \mathrm{a}$ & $76.6 \mathrm{a}$ & $75.0 \mathrm{a}$ & $25.6 \mathrm{~b}$ & $11.9 \mathrm{c}$ & $37.5 c$ & $50.2 \mathrm{~b}$ & $26.0 \mathrm{~b}$ \\
\hline Average & & $107.4 \mathrm{~A}$ & $57.0 \mathrm{~A}$ & $20.2 \mathrm{~A}$ & $77.2 \mathrm{~A}$ & $75.7 \mathrm{~A}$ & $29.2 \mathrm{~A}$ & $15.3 \mathrm{~B}$ & $44.5 \mathrm{~B}$ & $47.4 \mathrm{~A}$ & $29.7 \mathrm{~A}$ \\
\hline \multirow{4}{*}{ Peat } & 0 & $107.4 \mathrm{a}$ & $58.1 \mathrm{a}$ & $17.0 \mathrm{a}$ & $75.1 \mathrm{a}$ & $73.3 \mathrm{a}$ & $31.2 \mathrm{a}$ & $21.4 \mathrm{a}$ & $52.6 \mathrm{a}$ & $44.9 \mathrm{a}$ & $533.7 \mathrm{a}$ \\
\hline & 20 & $108.3 \mathrm{a}$ & $59.4 \mathrm{a}$ & $17.6 \mathrm{a}$ & $77.0 \mathrm{a}$ & $76.0 \mathrm{a}$ & $32.0 \mathrm{a}$ & $21.4 \mathrm{a}$ & $53.4 \mathrm{a}$ & $44.3 \mathrm{a}$ & $627.9 \mathrm{a}$ \\
\hline & 40 & $105.5 \mathrm{a}$ & $57.8 \mathrm{a}$ & $13.8 \mathrm{a}$ & $71.6 \mathrm{a}$ & $72.0 \mathrm{a}$ & $30.9 \mathrm{a}$ & $22.8 \mathrm{a}$ & $53.7 \mathrm{a}$ & $41.2 \mathrm{a}$ & $560.2 \mathrm{a}$ \\
\hline & 80 & 109.7 a & $58.8 \mathrm{a}$ & $15.4 \mathrm{a}$ & $74.2 \mathrm{a}$ & $76.7 \mathrm{a}$ & $25.9 \mathrm{~b}$ & $18.3 \mathrm{~b}$ & $44.2 \mathrm{~b}$ & $42.7 \mathrm{a}$ & $618.3 \mathrm{a}$ \\
\hline Average & & $107.7 \mathrm{~A}$ & $58.5 \mathrm{~A}$ & $16.0 \mathrm{~A}$ & $74.5 \mathrm{~B}$ & $74.5 \mathrm{~A}$ & $30.0 \mathrm{~A}$ & $21.0 \mathrm{~A}$ & $51.0 \mathrm{~A}$ & $43.3 \mathrm{~B}$ & $585.0 \mathrm{~A}$ \\
\hline
\end{tabular}

* Result presented are the average of 3 replicates. Means followed by the same letter are not significantly different by the Tukey's test at $P \leq 0.05$. Upper case letters, in columns, compare plant tissues and lower case letters, in columns, compare rate of amendments.

TABLe 4: Dry matter yield for different plant parts of the species tested according to the rate of organic material treatment*.

\begin{tabular}{|c|c|c|c|c|c|c|c|c|c|c|c|}
\hline & \multirow{2}{*}{ Rate } & \multicolumn{4}{|c|}{ Oilseed radish } & \multicolumn{4}{|c|}{ Sunflower } & \multicolumn{2}{|c|}{ Castor oil plant } \\
\hline & & Root & $\begin{array}{c}\text { Straw } \\
(\mathrm{S})\end{array}$ & Pod (P) & $\mathrm{S}+\mathrm{P}$ & Roos & $\begin{array}{l}\text { Straw } \\
(S)\end{array}$ & $\begin{array}{l}\text { Flower } \\
(\mathrm{F})\end{array}$ & $S+F$ & Roots & Shoots \\
\hline & $\mathrm{Mgha}^{-1}$ & \multicolumn{10}{|c|}{$\mathrm{mg} \mathrm{kg}^{-1}$} \\
\hline \multirow{4}{*}{$\begin{array}{l}\text { Sugar cane } \\
\text { filter cake }\end{array}$} & 0 & $0.8 \mathrm{a}$ & $10.8 \mathrm{a}$ & $5.0 \mathrm{a}$ & $15.7 \mathrm{a}$ & $2.2 \mathrm{a}$ & $12.7 \mathrm{~b}$ & $4.9 \mathrm{a}$ & $17.6 \mathrm{~b}$ & $4.7 \mathrm{a}$ & $18.5 \mathrm{~b}$ \\
\hline & 20 & $0.7 \mathrm{a}$ & $11.7 \mathrm{a}$ & $6.3 \mathrm{a}$ & $17.9 \mathrm{a}$ & $2.7 \mathrm{a}$ & $15.9 \mathrm{ba}$ & $3.4 \mathrm{~b}$ & $19.3 \mathrm{ba}$ & $5.8 \mathrm{a}$ & $19.5 \mathrm{ba}$ \\
\hline & 40 & $0.8 \mathrm{a}$ & $12.2 \mathrm{a}$ & $5.6 \mathrm{a}$ & $17.7 \mathrm{a}$ & $3.2 \mathrm{a}$ & $18.3 \mathrm{a}$ & $3.9 \mathrm{ba}$ & $22.2 \mathrm{a}$ & $5.6 \mathrm{a}$ & $21.3 \mathrm{c}$ \\
\hline & 80 & $0.7 \mathrm{a}$ & $12.5 \mathrm{a}$ & $5.7 \mathrm{a}$ & $18.2 \mathrm{a}$ & $2.4 \mathrm{a}$ & $15.0 \mathrm{ba}$ & $5.2 \mathrm{a}$ & $20.2 \mathrm{ba}$ & $5.6 \mathrm{a}$ & $20.7 \mathrm{bc}$ \\
\hline Average & & $0.8 \mathrm{~B}$ & $11.8 \mathrm{~A}$ & $5.6 \mathrm{~A}$ & $17.4 \mathrm{~A}$ & $2.6 \mathrm{~A}$ & $15.5 \mathrm{~A}$ & $4.4 \mathrm{~A}$ & $19.8 \mathrm{~A}$ & $5.4 \mathrm{~A}$ & $20.0 \mathrm{~A}$ \\
\hline \multirow{4}{*}{ Peat } & 0 & $0.9 \mathrm{a}$ & $12.1 \mathrm{a}$ & $4.8 \mathrm{a}$ & $16.9 \mathrm{a}$ & $1.6 \mathrm{a}$ & $12.7 \mathrm{a}$ & $3.2 \mathrm{a}$ & $15.8 \mathrm{a}$ & $4.4 \mathrm{a}$ & $18.5 \mathrm{~b}$ \\
\hline & 20 & $1.0 \mathrm{a}$ & $11.5 \mathrm{a}$ & $6.0 \mathrm{a}$ & $17.5 \mathrm{a}$ & $2.4 \mathrm{a}$ & $14.4 \mathrm{a}$ & $3.1 \mathrm{a}$ & $17.5 \mathrm{a}$ & $4.8 \mathrm{a}$ & $19.7 \mathrm{ba}$ \\
\hline & 40 & $0.9 \mathrm{a}$ & $12.6 \mathrm{a}$ & $5.0 \mathrm{a}$ & $17.6 \mathrm{a}$ & $2.0 \mathrm{a}$ & $13.3 \mathrm{a}$ & $3.3 \mathrm{a}$ & $16.7 \mathrm{a}$ & $5.1 \mathrm{a}$ & $18.9 \mathrm{~b}$ \\
\hline & 80 & $1.0 \mathrm{a}$ & $12.0 \mathrm{a}$ & $5.9 \mathrm{a}$ & $17.9 \mathrm{a}$ & $2.5 \mathrm{a}$ & $15.5 \mathrm{a}$ & $3.0 \mathrm{a}$ & $18.5 \mathrm{a}$ & $5.4 \mathrm{a}$ & $20.8 \mathrm{a}$ \\
\hline Average & & $0.9 \mathrm{~A}$ & $12.0 \mathrm{~A}$ & $5.5 \mathrm{~A}$ & $17.5 \mathrm{~A}$ & $2.1 \mathrm{~B}$ & $14.0 \mathrm{~B}$ & $3.2 \mathrm{~B}$ & $17.1 \mathrm{~B}$ & $4.9 \mathrm{~B}$ & $19.5 \mathrm{~B}$ \\
\hline
\end{tabular}

${ }^{*}$ Results presented are the average of 3 replicates. Means followed by the same letter, are not significantly different by the Tukey's test at $P \leq 0.05$. Upper case letters, in columns, compare plant tissues and lower case letters, in columns, compare rate of amendments.

filter cake was used. Sugar cane filter cake has a low $\mathrm{C} / \mathrm{N}$ ratio (Table 1), which may explain the trend to be a more useful source of nutrients than peat, as sugar cane is more easily decomposed than peat. Figure 1 shows that the increased organic material positively affected the shoot dry matter yield in the castor oil plants. However, despite the statistical significance of the regression models, from the agronomic or ecological point of view no marked quantitative difference in dry matter production among treatments would be enough to recommend one amendment over the other since the increase in dry matter production was, overall, discrete.

The addition of organic material to the soil affected differently $\mathrm{Ba}$ concentration among the three plant species (Table 3). Oilseed radish did not show a significant effect, but an increase in $\mathrm{Ba}$ in the castor oil plant roots was observed after the addition of sugar cane filter cake, from $39.8 \mathrm{mg} / \mathrm{kg}$ (no addition) to $50.2 \mathrm{mg} / \mathrm{kg}\left(80 \mathrm{Mg} \mathrm{ha}^{-1}\right)$, which corresponded to an increase of $26 \%$. In castor bean shoots,
Ba increased from $533.7 \mathrm{mg} / \mathrm{kg}$ in the control to $618 \mathrm{mg} / \mathrm{kg}$ in soils amended with $80 \mathrm{Mg} \mathrm{ha}^{-1}$ peat respectively, which represented an increase of $16 \%$. In sunflowers, the $\mathrm{Ba}$ concentrated in the flowers and straw+flower tissues was higher when the sugar cane filter cake was used. Moreover, the increase in the organic material rate (sugar cane filter cake and peat) resulted in a linear decrease in the Ba concentration in the flowers of the sunflower plants (Figure 2), up to $15 \%$ with sugar cake filter cake and $16 \%$ with peat addition.

When peat was used a negative correlation was observed for $\mathrm{Ba}$ and $\mathrm{P}$ in the castor oil plants $(r=-0.55)$ and sunflower tissues $(r=-0.48)$ (Table 5$)$. The same trend was observed for $\mathrm{K}$ in the oilseed radish $(r=-0.83)$ and $\mathrm{Ca}$ in the castor oil plants $(r=-0,67)$ and sunflowers $(r=0.52)$ with the use of sugar cane filter cake (Table 5). A nutritional imbalance of $\mathrm{Ca}, \mathrm{K}$, and $\mathrm{S}$ in the presence of $\mathrm{Ba}$ has been reported by several authors. These reports suggest that the imbalance is related to the plant species $[7,8,31]$. 
TABLE 5: Correlation between $\mathrm{Ba}$ and $\mathrm{P}, \mathrm{K}$ and $\mathrm{Ca}$ concentrations in shoots.

\begin{tabular}{|c|c|c|c|c|c|c|}
\hline \multirow{2}{*}{ Element } & \multicolumn{2}{|c|}{ Oilseed radish } & \multicolumn{2}{|c|}{ Sunflower } & \multicolumn{2}{|c|}{ Castor oil plant } \\
\hline & $\begin{array}{c}\text { Sugar } \\
\text { canefilter } \\
\text { cake }\end{array}$ & Peat & $\begin{array}{l}\text { Sugar cane } \\
\text { filter cake }\end{array}$ & Peat & $\begin{array}{l}\text { Sugar cane } \\
\text { filter cake }\end{array}$ & Peat \\
\hline $\mathrm{P}$ & $0.51^{*}$ & $0.07 \mathrm{NS}$ & $0.76^{*}$ & $-0.48 \mathrm{NS}$ & $-0.78^{*}$ & $0.55^{*}$ \\
\hline K & $-0.52^{*}$ & $-0.83^{*}$ & $0.12 \mathrm{NS}$ & $-0.00 \mathrm{NS}$ & $0.78^{*}$ & $0.42 \mathrm{NS}$ \\
\hline $\mathrm{Ca}$ & $-0.05 \mathrm{NS}$ & $0.13 \mathrm{NS}$ & $-0.52^{*}$ & $-0.04 \mathrm{NS}$ & $0.73^{*}$ & -0.67 \\
\hline
\end{tabular}

* Significant at $P<0.05$ and NS: not significant.

TABLE 6: Transfer factor (TF) and translocation index (TI) of Ba in the tested species.

\begin{tabular}{|c|c|c|c|c|c|c|c|}
\hline \multirow{2}{*}{ Treatment } & \multirow{2}{*}{$\mathrm{Mg} \mathrm{ha}^{-1}$} & \multicolumn{3}{|c|}{$\mathrm{TF}$} & \multicolumn{3}{|c|}{ TI (\%) } \\
\hline & & $\begin{array}{l}\text { Oilseed } \\
\text { radish }\end{array}$ & Sunflower & $\begin{array}{c}\text { Castor oil } \\
\text { plant }\end{array}$ & $\begin{array}{c}\text { Oilseed } \\
\text { radish }\end{array}$ & $\begin{array}{c}\text { Castor oil } \\
\text { plant }\end{array}$ & Sunflower \\
\hline \multirow{4}{*}{$\begin{array}{l}\text { Sugar cane } \\
\text { filter cake }\end{array}$} & 0 & 0.70 & 0.47 & 0.26 & 89.23 & 74.64 & 59.22 \\
\hline & 20 & 0.70 & 0.46 & 0.32 & 90.63 & 66.71 & 60.92 \\
\hline & 40 & 0.69 & 0.45 & 0.29 & 90.32 & 71.77 & 60.45 \\
\hline & 80 & 0.65 & 0.41 & 0.28 & 90.52 & 65.70 & 60.13 \\
\hline \multirow[t]{2}{*}{ Average } & & 0.69 & 0.45 & 0.29 & 90.20 & 69.57 & 60.21 \\
\hline & 0 & 0.75 & 0.52 & 0.30 & 89.01 & 72.86 & 59.59 \\
\hline \multirow{3}{*}{ Peat } & 20 & 0.71 & 0.49 & 0.29 & 88.24 & 74.76 & 59.87 \\
\hline & 40 & 0.68 & 0.48 & 0.27 & 89.52 & 72.69 & 59.37 \\
\hline & 80 & 0.71 & 0.47 & 0.28 & 88.10 & 72.98 & 59.82 \\
\hline Average & & 0.71 & 0.49 & 0.29 & 88.71 & 73.35 & 59.66 \\
\hline
\end{tabular}

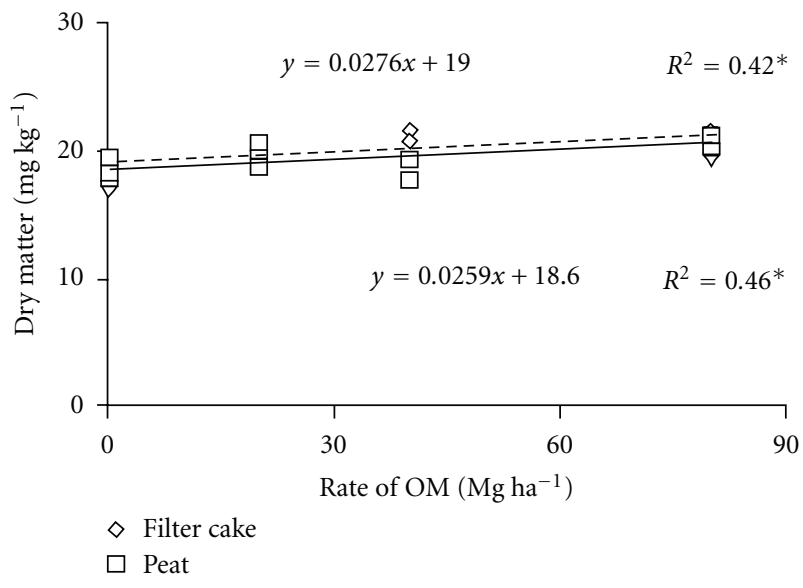

FIGURE 1: Effect of increasing concentrations of organic materials on shoot dry matter yield in castor oil plants shoots (d.w.). Significant at $P<0.05$.

The transfer index (calculated as the Ba shoot concentration divided by the total $\mathrm{Ba}$ in the soil) decreased as follows: oilseed radish $(0.70)>$ sunflowers $(0.47)>$ castor oil plants (0.29). The average Ba transfer from the roots to the shoots in the oilseed radish, castor oil plants, and sunflowers was found to be $89 \%, 71 \%$, and $59 \%$, respectively. These values indicated that the $\mathrm{Ba}$ was highly mobile in the xylem of the oilseed radish and castor oil plants. From the total $\mathrm{Ba}$ transfer values, at least $50 \%$ of the Ba shoot concentration

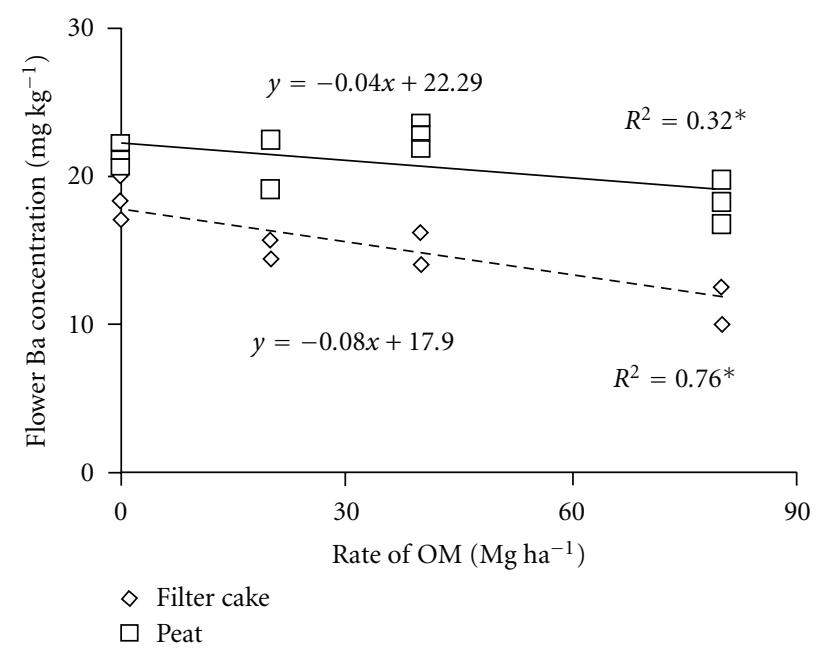

FIGURE 2: Effect of increasing concentrations of organic materials on Ba concentration in the flowers of sunflowers (d.w.). Significant at $P<0.05$.

was found in the flowers of the sunflowers, and 35\% of the $\mathrm{Ba}$ shoot concentration was found in the pods of the oilseed radish (Table 3 ). Ba concentrations in flowers with the addition of sugar cane filter cake and peat were as follows: 20.2 and $16.0 \mathrm{mg} \mathrm{kg}^{-1}$, respectively, for oilseed radish; 15.3 and $21.0 \mathrm{mg} \mathrm{kg}^{-1}$, respectively, for sunflowers. A high $\mathrm{Ba}$ mobility has also been observed in cotton and white beets 
during development and flowering, whereas a large amount of $\mathrm{Ba}$ accumulation has been reported in the leaves of corn $\left(105.7 \mathrm{mg} \mathrm{kg}^{-1}\right)$ when compared with the grains of corn (1.05 $\left.\mathrm{mg} \mathrm{kg}^{-1}\right)$ [6, 33].

The obtained transfer factors (lower than 1) suggested that the tested species were inadequate in accumulating or extracting $\mathrm{Ba}$ from soil (Table 6). Similarly, low transfer factors have also been reported for castor oil plants, sunflowers, and mustard plants [30]. Indeed, these authors [30] reported that none of the plants grown in soils containing $\mathrm{Ba}$ ranging from 132.3 to $1,130 \mathrm{mg} \mathrm{kg}^{-1}$ were able to accumulate measurable concentrations of $\mathrm{Ba}$, thus, highlighting the low transfer of this element from soil to plants [34].

A decreasing trend for $\mathrm{Ba}$ transfer to oilseed radish and sunflowers was found when the sugar cane filter cake concentration increased (Table 6). In addition to improving the physical and chemical conditions of the soil, organic ligands are promising in the mitigation of heavy metal contaminated soils. Peat and a concentrate containing humic substances from coal favor mustard development in a contaminated soil due to the mitigation of $\mathrm{Zn}, \mathrm{Cu}, \mathrm{Mn}, \mathrm{Pb}$, and $\mathrm{B}$ by the organic ligands [14].

\section{Conclusions}

Under the conditions studied the elevated soil $\mathrm{pH}$ reached due to liming overcame the organic matter addition effect and determined the barium availability and its absorption by the plant species grown in the area polluted with scrap metal residue. This is suggested by the absence of phytotoxic effects on plants, the moderate $\mathrm{Ba}$ accumulation in shoots compared to the usual content of Ba in plants, the small effect of organic matter treatments on plants dry matter yields, and finally the levels of Ba extracted by Mehlich-3.

\section{Acknowledgment}

The authors would like to thank Fundação de Apoio a Pesquisa do Estado de São Paulo (FAPESP) for the financial support with the 2006/60987-0 Research Grant.

\section{References}

[1] Cetesb, "Relatório de Totalização de áreas contaminadas e rea- bilitadas-Dezembro de 2010," 2011, http://www.cetesb.sp .gov.br/areas-contaminadas/relacoes-de-areas-contaminadas/ 15-publicacoes.

[2] J. A. Ippolito and K. A. Barbarick, "Biosolids affect soil barium in a dryland wheat agroecosystem," Journal of Environmental Quality, vol. 35, no. 6, pp. 2333-2341, 2006.

[3] L. C. S. Merlino, W. Melo, F. G. Macedo et al., "Barium, cadmium, chromium and lead in maize plants and in an oxisol after eleven years of sewage sludge applications," Revista Brasileira de Ciência do Solo, vol. 34, pp. 2031-2039, 2010.

[4] E. Simon, M. Braun, A. Vidic, D. Bogyo, I. Fabian, and B. Tothneresz, "Air pollution assessment ion elemental concentration of leaves tissue and foliage dust along an urbanization gradient in Vienna," Environmental Pollution, vol. 159, pp. 1229-1233, 2011.
[5] E. Nogaj, J. Kwapulinski, and H. Misiolek, "Pharyngeal Tonsil as new biomarker of pollution on example of barium," Polish Journal of Environmental Studies, vol. 20, pp. 161-172, 2011.

[6] T. A. R. Nogueira, W. J. deMelo, I. M. Fonseca, M. O. Marques, and Z. He, "Barium uptake by maize plants as affected by sewage sludge in a long-term field study," Journal of Hazardous Materials, vol. 181, no. 1-3, pp. 1148-1157, 2010.

[7] M. Llugany, C. Poschenrieder, and J. Barceló, "Assessment of barium toxicity in bush beans," Archives of Environmental Contamination and Toxicology, vol. 39, no. 4, pp. 440-444, 2000.

[8] R. Suwa, K. Jayachandran, N. T. Nguyen, A. Boulenouar, K. Fujita, and H. Saneoka, "Barium toxicity effects in soybean plants," Archives of Environmental Contamination and Toxicology, vol. 55, no. 3, pp. 397-403, 2008.

[9] C. A. Menzie, B. Southworth, G. Stephenson, and N. Feisthauer, "The importance of understanding the chemical form of a metal in the environment: the case of barium sulfate (barite)," Human and Ecological Risk Assessment, vol. 14, no. 5, pp. 974-991, 2008.

[10] F. Baldi, M. Pepi, D. Burrini, G. Kniewald, D. Scali, and E. Lanciotti, "Dissolution of barium from barite in sewage sludges and cultures of Desulfovibrio desulfuricans," Applied and Environmental Microbiology, vol. 62, no. 7, pp. 2398-2404, 1996.

[11] A. A. Carbonell, R. Pulido, R. D. DeLaune, and W. H. Patrick, "Soluble barium in barite and phosphogypsum amended Mississippi River alluvial sediment," Journal of Environmental Quality, vol. 28, no. 1, pp. 316-321, 1999.

[12] G. A. Ulrich, G. N. Breit, I. M. Cozzarelli, and J. M. Suflita, "Sources of sulfate supporting anaerobic metabolism in a contaminated aquifer," Environmental Science and Technology, vol. 37, no. 6, pp. 1093-1099, 2003.

[13] C. M. Davidson, M. D. Gibson, E. Hamilton, B. H. MacGillivray, J. Reglinski, and E. Rezabal, "The long-term environmental behaviour of strontium and barium released from former mine workings in the granites of the Sunart region of Scotland, UK," Chemosphere, vol. 58, no. 6, pp. 793-798, 2005.

[14] G. C. G. Dos Santos and A. A. Rodella, "Effect of sources of organic matter in the alleviation of the toxic effects of $\mathrm{B}, \mathrm{Zn}$, $\mathrm{Cu}, \mathrm{Mn}$ and $\mathrm{Pb}$ to Brassica Juncea," Revista Brasileira de Ciencia do Solo, vol. 31, no. 4, pp. 793-804, 2007.

[15] J. C. Corrêa, L. T. Büll, W. D. S. Paganini, and I. A. Guerrini, "Heavy metal exchangeable in an Oxisol with surface application of flue dust, aqueous lime, sewage sludge and limestone," Pesquisa Agropecuaria Brasileira, vol. 43, no. 3, pp. 411419, 2008.

[16] E. E. C. de Melo, C. W. A. do Nascimento, A. C. Q. Santos, and A. S. da Silva, "Availability and fractionation of Cd, Pb, $\mathrm{Cu}$, and $\mathrm{Zn}$ in soil as a function of incubation time and $\mathrm{pH}$," Ciencia e Agrotecnologia, vol. 32, no. 3, pp. 776-784, 2008.

[17] O. C. Bataglia, A. M. C. Furlani, J. P. F. Teixeira, and J. R. Gallo, Métodos de Análise Química de Plantas, Boletim Técnico, 78, Instituto Agronômico, Campinas, Brazil, 1983.

[18] United States Environmental Protection Agency, "Method 3051: microwave assisted acid digestion of sediments, sludges, soil and soils," 2009, http://www.epa.gov/epaoswer/hazwaste/ test/3_series.htm.

[19] Empresa Brasileira de Pesquisa Agropecuária, Brazilian System of Soil Classification, vol. 306, Embrapa-Centro Nacional de Pesquisa de Solos, Rio de Janeiro, Brazil, 2nd edition, 2006.

[20] B. van Raij, J. C. Andrade, H. Cantarella, and J. A. Quaggio, Análise Química Para Avaliação da Fertilidade de Solos Tropicais, Instituto Agronômico, Campinas, Brazil, 2001. 
[21] C. De Freitas Zeitouni, R. S. Berton, and C. A. De Abreu, "Phytoextraction of cadmium and zinc from an oxisol contaminated with heavy metals," Bragantia, vol. 66, no. 4, pp. 649657, 2007.

[22] A. M. M. Pires, C. A. Abreu, A. R. Coscione, V. A. Silva, and N. P. Ramos, "Initial growth of sunflower in soils with high concentrations of boron and heavy metals," in Proceedings of the 17th International Sunflower Conference, vol. 2, pp. 315318, Córdoba, Spain, 2008.

[23] G. C. G. dos Santos, A. A. Rodella, C. A. de Abreu, and A. R. Coscione, "Vegetable species for phytoextraction of boron, copper, lead, manganese and zinc from contaminated soil," Scientia Agricola, vol. 67, no. 6, pp. 713-719, 2010.

[24] R. A. B. Jorge, C. A. de Abreu, C. A. de Andrade, and O. A. de Camargo, "Filter cake and peat as amendments of contaminated soil with residue of scrap rich in boron," Bragantia, vol. 69, no. 2, pp. 467-476, 2010.

[25] A. Mehlich, "Mehlich 3 soil test extractant: a modification of Mehlich 2 extractant," Communications in Soil Science and Plant Analysis, vol. 15, no. 12, pp. 1409-1416, 1984.

[26] A. D. Abichequer and H. Bohnen, "Efficiency of phosphorus uptake, translocation and utilization in wheat varieties," $R e$ vista Brasileira de Ciência do Solo, vol. 22, pp. 21-26, 1998.

[27] S. Lubben and D. Sauerbeck, "The uptake and distribution of heavy metals by spring wheat," Water, Air, and Soil Pollution, vol. 57-58, pp. 239-247, 1991.

[28] Companhia de Tecnologia de Saneamento Ambiental, "Guiding values for soils and groundwater in the State of Sao Paulo," 2011, http://www.cetesb.sp.gov.br/Solo/relatorios/tabela_valores_2005.pdf.

[29] M. B. Gabos, G. Casagrande, C. A. Abreu, and J. PazFerreiro, "Uso da matéria orgânica como mitigadora de solo multicontaminado e do girassol como fitoextratora," Revista Brasileira de Engenharia Agrícola e Ambiental, vol. 15, no. 12, pp. 1298-1306, 2011.

[30] A. R. Coscione and R. S. Berton, "Barium extraction potential by mustard, sunflower and castor bean," Scientia Agricola, vol. 66, no. 1, pp. 59-63, 2009.

[31] F. M. Chaudhry, A. Wallace, and R. T. Mueller, "Barium toxicity in plants," Communications in Soil Science and Plant Analysis, vol. 8, no. 9, pp. 795-797, 1977.

[32] I. Pais and J. R. Jones, The Handbook of Trace Elements, St. Lucie Press, Boca Ratón, Fla, USA, 1998.

[33] Z. En, A. Vasidov, V. V. Tsipin, T. Tillaev, and G. I. Jumaniyazova, "Study of element uptake in plants from the soil to assess environmental contamination by toxic elements," $\mathrm{Nu}$ clear Instruments and Methods in Physics Research A, vol. 505, no. 1-2, pp. 462-465, 2003.

[34] J. Pichtel, K. Kuroiwa, and H. T. Sawyerr, "Distribution of $\mathrm{Pb}, \mathrm{Cd}$ and $\mathrm{Ba}$ in soils and plants of two contaminated sites," Environmental Pollution, vol. 110, no. 1, pp. 171-178, 2000. 

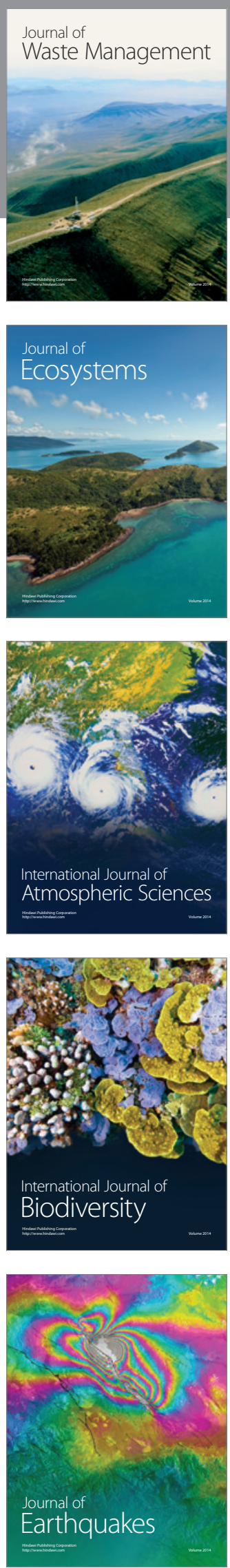
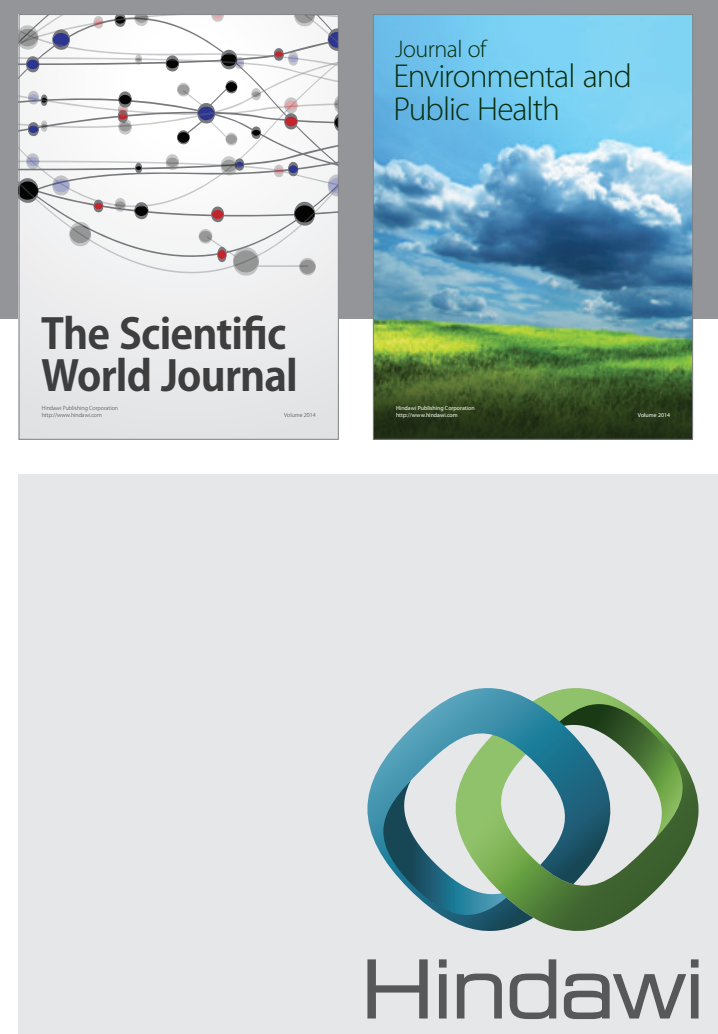

Submit your manuscripts at

http://www.hindawi.com
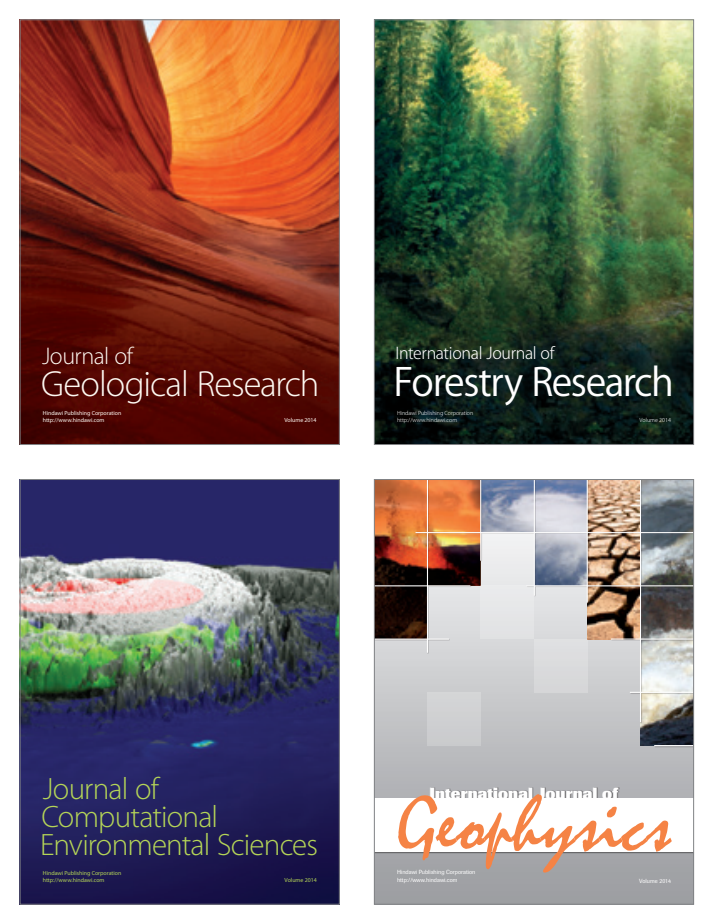
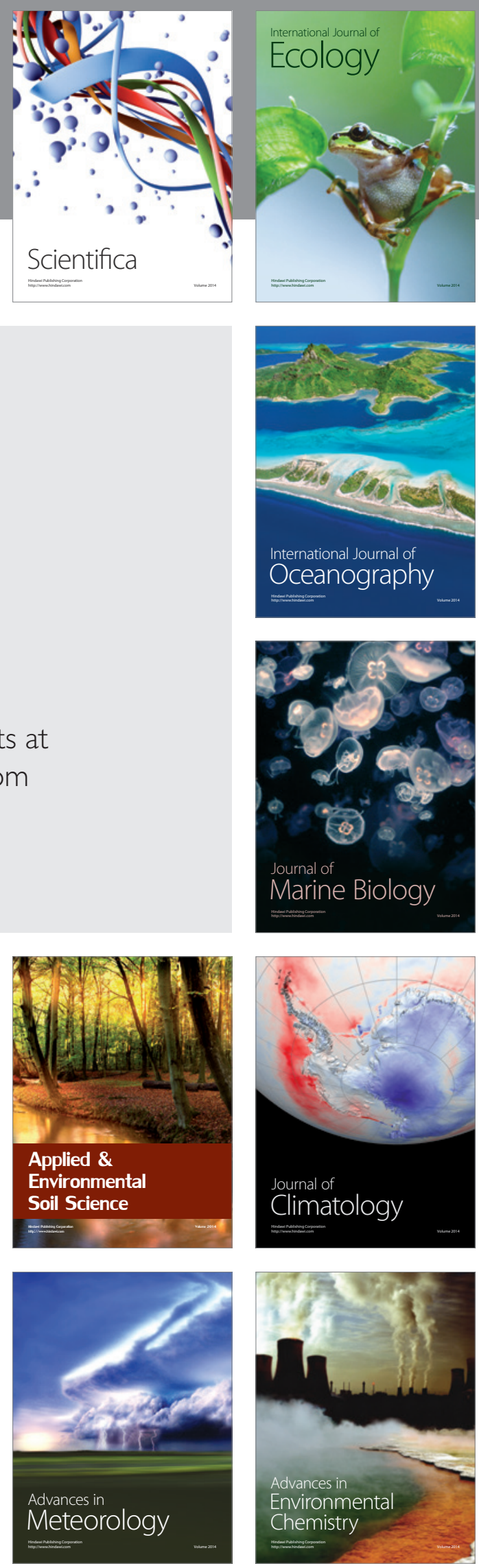